\title{
Bahasa sebagai Alat Komunikasi, Citra Pikiran, dan Kepribadian
}

\author{
Noermanzah \\ Program Studi Magister Pendidikan Bahasa Indonesia, Universitas Bengkulu \\ (Dipresentasikan Tahun 2020) \\ Surel: noermanzah@unib.ac.id, Laman: http://noermanzah.staff.unib.ac.id/
}

\begin{abstract}
Abstrak
Makalah ini bertujuan memberikan pemahaman tentang hakikat bahasa sebagai alat komunikasi, citra pikiran, dan kepribadian. Bahasa sebagai alat komunikasi bermakna bahwa bahasa merupakan deretan bunyi yang bersistem, berbentuk lambang, bersifat arbitrer, bermakna, konfensional, unik, universal, produktif, bervariasi, dinamis, manusiawi, dan alat interaksi sosial yang menggantikan individual dalam menyatakan sesuatu atau berekspresi kepada lawan tutur dalam suatu kelompok sosial sebagai alat untuk berkomunikasi dan identitas penuturnya. Bahasa sebagai citra pikiran bermakna bahwa bahasa terbentuk dari pikiran, atau bentuk bahasa (secara individual dan spontan) meniru atau mengikuti bentuk pikiran atau ide. Bahasa sebagai citra kepribadian bermakna bahwa bahasa berkaitan dengan etika berbahasa yang diyakininya. Etika berbahasa ini sangat erat berkaitan dengan pemilihan kode bahasa, norma-norma sosial, dan sistem budaya yang berlaku dalam satu masyarakat. Dengan menggunakan bahasa dengan memperhatikan etika berbahasa maka pribadi seseorang akan dikatakan baik.
\end{abstract}

Kata kunci: hakikat bahasa, alat komunikasi, citra pikiran, citra kepribadian

\section{A. Pendahuluan}

Manusia diciptakan oleh Tuhan Yang Maha Esa ke dunia memiliki tujuan yang tidak lain menjadi khalifah. Khalifah mengandung makna pemimpin dan pemelihara alam semesta. Pertanyaannya adalah "Bagaimanakah tujuan manusia sebagai khalifah dapat dicapai? Tuhan YME sudah mempersiapkannya dengan sempurna yaitu dilengkapinya manusia dengan bahasa.

Bahasa yang dimilki oleh manusia merupakan ciri pembeda dengan makhluk ciptaan Tuhan YME yang lainnya. Dengan bahasa kita mampu memahami sebenarnya apa yang diharapkan oleh alam semesta baik yang bersifat material maupun yang bersifat metafisika dan dengan bahasa kita mampu berinteraksi dan berkomunikasi dengan manusia lainnya di dunia sehingga dengan bahasa kita mampu mengubah dunia ini menjadi berwarna. Dua hal ini yang membedakan bahasa manusia dengan bahasa yang dimiliki oleh makhluk ciptaan-Nya yang lain. 
Sedari kecil kita sudah menggunakan bahasa yang sederhana seperti 'oe' berkembang menjadi "Mama/Papa" berkembang menjadi 'Cayang' berkembang menjadi 'Aku Sayang Kamu' dan berkembang menjadi 'Sejak aku memandangmu, bergetar jantung dan darahku dan .... Dalam hal ini bahasa berkembang sesuai dengan perkembangan alat komunikasi, perkembangan fisik manusia (fonem, morfologi, sintaksis, dan wacana), dan perkembangan peran manusia dalam kehidupan. Kemudian, pertanyaannya Apakah kita menyadari perkembangan bahasa kita? Atau sudahkah kita menyadari bahasa yang kita gunakan dari kecil sampai sekarang sudah menjadi bagian utama yang mengubah kita menjadi manusia yang memahami benar dan salah, manusia yang selalu ingin lebih baik dari hari ke hari? Jawabannya pasti kita ada yang tidak menyadarinya. Untuk itu, makalah ini bertujuan untuk menjawab bahwa pentingnya pembahasan dalam memahami hakikat bahasa baik sebagai alat komunikasi, citra pikiran, dan citra kepribadian.

Bahasa juga penting ketika kita akan mengembangkan empat keterampilan bahasa, yaitu berbicara, menyimak, membaca, dan menulis (Noermanzah dkk., 2018:172). Dengan menguasai keempat keterampilan berbahasa tersebut pada dasarkan kita mampu berkomunikasi dengan baik dan mampu melakukan perubahan-perubahan terhadap kemajuan pribadi, masyarakat, dan bangsa. Terlebih sekarang peserta didik dituntut untuk mendayagunakan bahasa untuk bisa berkomunikasi dengan baik dan santun, kreatif, berpikir kritis, berkerja sama, dan berkolaborasi, dan (Kusmiarti, 2020:207) Untuk itu, pentingnya mengaji bahasa bukan hanya sebagai alat komunikasi, tetapi sebagai citra pikiran, dan kepribadian.

\section{B. Pembahasan}

\section{Bahasa sebagai Alat Komunikasi}

Devitt \& Hanley (2006:1);Noermanzah (2017:2) menjelaskan bahwa bahasa merupakan pesan yang disampaikan dalam bentuk ekspresi sebagai alat komunikasi pada situasi tertentu dalam berbagai aktivitas. Dalam hal ini ekspresi berkaitan unsur segmental dan suprasegmental baik itu lisan atau kinesik sehingga sebuah kalimat akan bisa berfungsi sebagai alat komunikasi dengan pesan yang berbeda apabila disampaikan dengan ekspresi yang berbeda. Kemampuan berbahasa ini 
diimplementasikan dengan kemampuan dalam beretorika, baik beretorika dalam menulis maupun berbicara. Retorika dalam hal ini sebagai kemampuan dalam mengolah bahasa secara efektif dan efisien berupa ethos (karakter atau niat baik), pathos (membawa emosional pendengar atau pembaca), dan logos (bukti logis) sehingga mempengaruhi pembaca atau pendengar dengan pesan yang disampaikan melalui media tulis atau lisan (Noermanzah dkk., 2017:222-223; Noermanzah dkk., 2018;119).

Ronal Wardhaugh mengungkapkan bahasa sebagai 'a system of arbitrary vocal symbol used for human communication'. Dari pengertian tersebut mengandung makna bahwa bahasa merupakan suatu sistem simbol-simbol bunyi yang arbitrer yang digunakan untuk komunikasi manusia (dalam Pateda, 2011:6). Hal yang senada juga dikemukan Bloch dan Trager bahwa bahasa sebagai 'Language is a system of arbitray vocal symbol by means of which a social group cooperates' yang artinya bahasa sebagai sistem simbol-simbol bunyi yang arbitrer yang dipergunakan oleh suatu kelompok sosial sebagai alat untuk berkomunikasi.

Bahasa menurut Pateda (2011:7) merupakan deretan bunyi yang bersistem sebagai alat (instrumentalis) yang menggantikan individual dalam menyatakan sesuatu kepada lawan tutur dan akhirnya melahirkan kooperatif di antara penutur dan lawan tutur. Dalam hal ini dapat dijelaskan bahwa bahasa dalam wujud bunyi yang bersistem tersebut memiliki peran pengganti bagi penutur untuk menyatakan gagasannya yang kemudian direspons oleh lawan tutur sehingga terjalin komunikasi yang baik.

Kemudian, bahasa juga dijelaskan secara rinci oleh Chaer (2012:33) berupa sistem, berbentuk lambang, berbentuk bunyi, bersifat arbitrer, bermakna, konfensional, unik, universal, produktif, bervariasi, dinamis, manusiawi, digunakan sebagi alat interaksi sosial, dan berfungsi sebagai identitas penuturnya. Chaer lebih menjelaskan bahasa sebagai alat komunikasi yang memiliki ciri-ciri khusus yang membedakannya dengan bahasa yang dimiliki oleh makhluk ciptaan Tuhan yang lain atau bisa dikatakan bahasa merupakan hak milik manusia sebagai insan yang mampu berkomunikasi dan karnanya manusia bisa berkembang dan bertahan hidup. 
Bunyi yang dimaksud dalam bahasa menurut G.A. Miller (1974:8, dalam Pateda, 2011:7) berisi beberapa hal, di antaranya:

a. Pholological information, informasi yang bersifat fonologis, bunyi yang tata makna.

b. Syntctic information, informasi yang dikemukakan dalam wujud kalimat.

c. Lexical information, informasi yang terdapat dalam setiap laksem.

d. Conceptual knowledge, konsep-konsep.

e. Have some system of beliefs in order to evaluate what he hears.

Kemudian, menurut Hill (1958:3-9) menjelaskan terdapat lima sifat bahasa yang berwujud bunyi, sebagai berikut:

a. Bahasa merupakan seperangkat bunyi yang bersistem dan dikeluarkan oleh alat bicara manusia.

b. Hubungan antara bunyi bahasa dan objek (reference) bersifat arbitrary (manasuka). Artinya, hubungan antara bunyi dan wujudnya yang berwujud benda, atau konsep bersifat manasuka. Buktinya bunyi cai dalam bahasa Sunda, air dalam bahasa Indonesia, dan water dalam bahasa Inggris.

c. Bahasa itu bersistem. Setiap bahasa di dunia ini mempunyai sistem sendiri. Sistem bahasa Indonesia berbeda dengan sistem bahasa Inggris dan bahasa lain di dunia ini.

d. Bahasa adalah seperangkat lambang. Memang bunyi yang dihasilkan oleh alat bicara manusia itu berwujud lambang. Misalnya, bunyi kuda lambangnya adalah /k,u,d,a/ kalau kita suarakan dan berwujud kuda kalau kita tuliskan dalam bahasa Indonesia (sebab dalam bahasa Inggris akan ditulis (h,o,r,s,e) . Lambang-lambang itu kita mengerti maknanya apabila lambang tersebut berada dalam kawasan bahasa yang kita pahami.

e. Bahasa bersifat sempurna, maksudnya bahasa yang kita gunakan dapat ditambahkan unsur lain bisa berwujud gerakan tangan, perubahan roman muka, atau penambahan unsur suprasegmental pada setiap satuan ujaran.

Dari beberapa pendapat di atas dapat disimpulkan bahasa sebagai alat komunikasi bermakna bahwa bahasa merupakan deretan bunyi yang bersistem, berbentuk lambang, bersifat arbitrer, bermakna, konfensional, unik, universal, 
produktif, bervariasi, dinamis, manusiawi, dan alat interaksi sosial yang menggantikan individual dalam menyatakan sesuatu atau berekspresi kepada lawan tutur dalam suatu kelompok sosial sebagai alat untuk berkomunikasi dan identitas penuturnya.

\section{Proses Bahasa}

Proses bahasa menurut Bloomfield (1933) digambarkan sebagai berikut:

$$
\begin{aligned}
& \mathrm{S} \\
& \mathrm{S}=\text { stimulus } \\
& \mathrm{R}=\text { respons }
\end{aligned}
$$

Brooks (1964:4) menggambarkan proses bahasa sebagai berikut:

A Language Event

Speaker
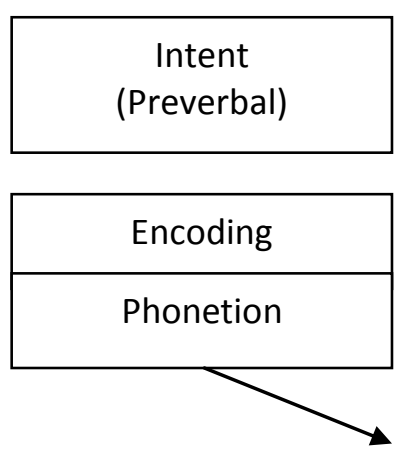

Speaker

Komprehension

(Post Verbal)

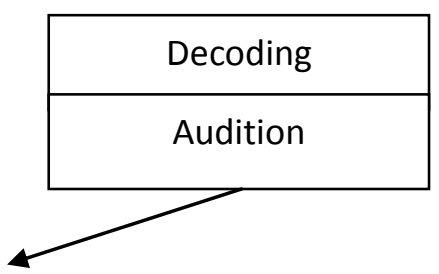

Transition

Kemudian, menurut F. De Saussure (terjemahan dalam bahasa Inggris oleh Wade Baskin (1977:12) menggambarkan proses bahasa sebagai berikut:
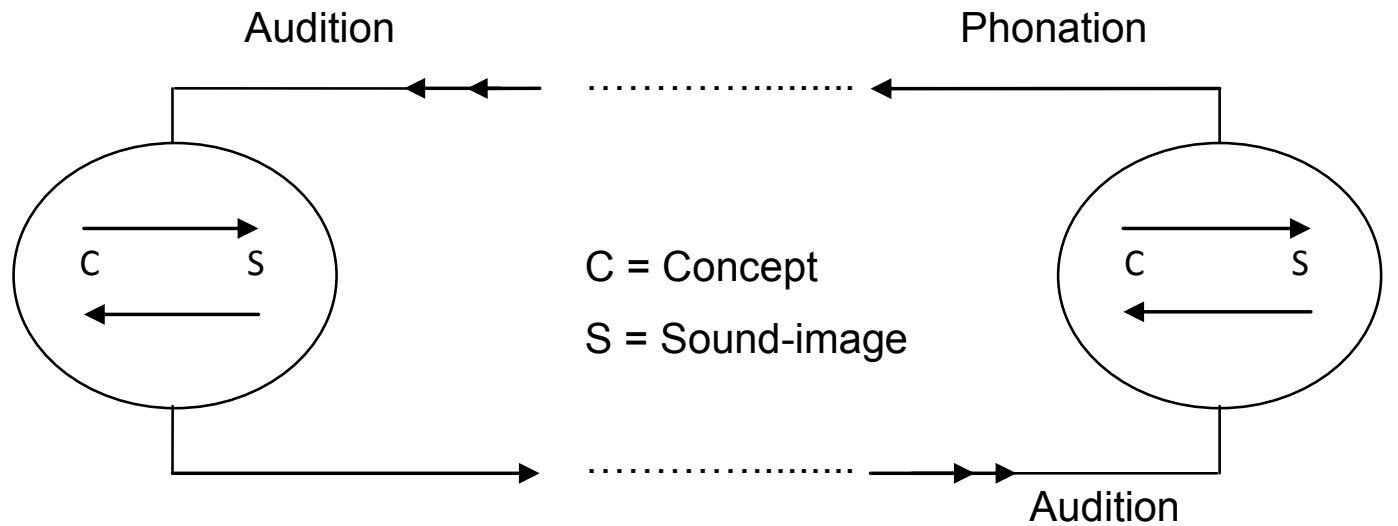

Dilihat dari segi neurophysiology, apa yang berhubungan dengan bahasa diatur di dalam hemifir kiri di tempat daerah Broca, Wernicke, dan konteks superior. 
Ketika daerah penting yang ada pada otak manusia dipusatkan dalam suatu sistem yang disebut sistem sentersefalk. (centercephalic system) yang letaknya diperkirakan di tengah-tengah di antara daerah Broca, Wernicke, dan konteks superior. Semua rangsangan termasuk yang lewat telinga dan mata yang masuk ke otak diperiksa dulu oleh sistem sentersefealik yang kemudian dikirim ke bagian-bagian yang dipilih untuk menanggapinya (Pateda, 2011:10).

Daerah yang khusus mengontrol ujaran disebut daerah Broca. Broca menurut Dardjowidjojo (1982:5) menjelaskan bahwa dasar ujaran bergantung pada empat faktor, di antaranya: sebuah ide; hubungan konvensional antara ide dan kata; cara penggandengan gerak artikulasi dengan kata; dan penggunaan alat-alat artikulasi.

Keempat unsur di atas ini harus ada sebab kalau tidak, akan terjadi-keanehankeanehan tertentu. Misalnya, kalau tidak terpenuhi faktor yang keempat, orang tidak dapat berbicara meskipun ia mengerti apa yang dibicarakan.

\section{Hubungan antara Bentuk dengan Makna}

Devitt dan Hanley (2006:4) menjelaskan bahwa makna dari sebuah ekspresi bahasa tergantung bagaimana penggunaannya: jika kita menggunakan kata 'kucing' untuk merujuk kepada anjing bukannya kucing itu akan memiliki arti yang berbeda karena adanya fakta atu kebenaran dan referensi yang mengacu pada bentuk. Makna sebuah kata yang disebabkan oleh "properti dasar penerimaan, " fakta bahwa makna ditentukan oleh kalimat yang diterima oleh penggunanya. Referensi, mempunyai makna "Apa yang Anda maksud? " Kurang lebih setara dengan " Apa yang kamu bicarakan? " Kalau ucapan itu kalimat deklaratif biasa, biasanya pertanyaan tentang apa subjek kalimat itu, dan investigasi menjadi referensi telah dimengerti difokuskan pada istilah dalam posisi subjek.

James Higginbottham (dalam Devitt dan Hanley, 2006:58-59) menjelaskan bahwa referensi adalah konsep sentral sebuah makna bahasa. Kemudian, lebih lanjut beliau menjelaskan bahwa komunikasi tidak harus kaku memisahkan bentuk referensi yang ditentukan oleh bentuk linguistik dari referensi dalam konteks. Hal ini berarti sebuah makna bahasa akan berubah seiring konteks di mana bahasa itu digunakan atau bahasa itu digunakan pada budaya tertentu dengan ekspresi tertentu. 
Misalnya, kata kalimat "Tak celurit sampeian" Yang diujarkan oleh dua orang sahabat di warung kopi dengan maksud sebagai ungkapan candaan. Padahal makna tak celurit sampeian bisa juga sebagai makna ungkapan rasa marah seseorang sehingga artinya bersifat literal yaitu Saya akan potong leher saudara pada konteks formal. Contoh lain, apabila kita mengungkapkan terima kasih dengan kepala tertunduk pada konteks formal akan berubah makna menjadi sindiran bukan mengungkapkan terima kasih.

Pateda (2011:11) menjelaskan bahwa alat bicara manusia yang menghasilkan bunyi bahasa terdiri dari dua unsur, yaitu bentuk (form) dan makna (meaning). Sedangkan Gleason (1961:2) mengemukakan dua unsur tersebut dinamakan "expression" dan "content", oleh Humboldt disebut "auzzere vorm" dan "innere vorm" oleh St. Takdir Alisyahbana (1972) disebut bentuk lahir dan bentuk batin, sedangkan oleh F. de Saussure (terjemahan Wade Baskin: 1974:67) disebut dengan signified (signifie) dan signifier (signifiant).

Permasalahannya sekarang apakah hubungan antara bentuk dan makna itu? Persoalan ini sebenarnya dapat kita rentangkan menjadi:

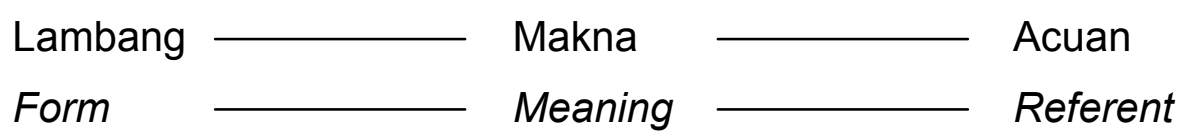

Hubungan "form" dan "meaning" kita contohkan hubungan antara ayam dan makna ayam. Kita mengetahui bahwa kuda dapat kita maknakan sebagai: sejenis hewan unggas, berkaki dua, berkuku ganjil, bertelur, dapat dipakai untuk dipotong (konsumsi), penghasil telur, hiasan, petarung dan sebagainya, serta dapat dibudidayakan dengan mudah. Persoalannya ialah apakah hubungan antara bunyi ayam dengan analisis makna yang kita sebut ayam itu? Mengapa tidak kita bunyikan ayom, yoma, iyem, tetapi justru ayam. Satu jawaban yang dapat dikemukakan yakni hubungannya bersifat konfensional.

Sekarang timbul lagi persoalan hubungan antara lambang (form) dan acuan (reference). Kita mengetahui bahwa untuk lambang. 


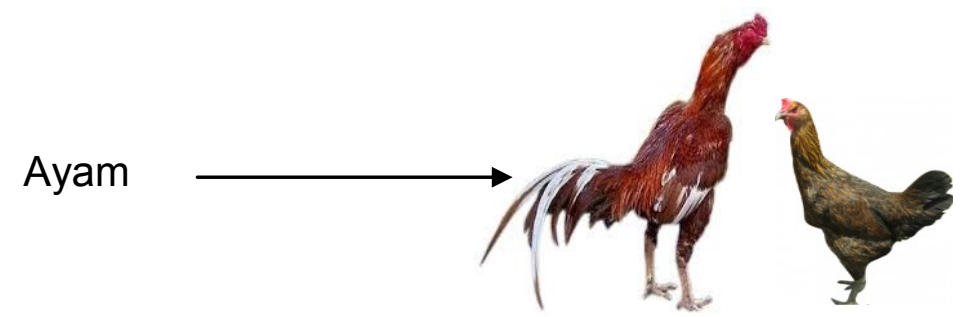

Akan tetapi, perlu kita ketahui bahwa acuan ayam terlalu banyak lambang yang dipergunakan. Kebetulan dalam bahasa Indonesia disebut ayam, tetapi di dalam bahasa Jawa disebut pitik, dalam bahasa Inggris disebut chiken. Bagaimana hubungan antara ayam dan acuannya, bersifat arbiter dan konvensional. Artinya kita tidak terlalu tahu sejak kapan ayam disebut ayam. Yang jelas sejak kita lahir binatang ini sudah bernama ayam.

Pada zaman Aristoteles dan Plato, telah dicari hubungan antara lambang dan acuannya. Satu kesimpulan yang dapat ditarik yaitu bahwa tidak ada hubungan antara lambang dengan acuannya. Hubungannya dianggap konvensional, sudah merupakan hasil perjanjian bersama yang telah berlaku turun-temurun.

\section{Proses Belajar Bahasa}

Ketika seseorang mulai belajar menguasai bahasa pertama (B1) mereka hidup dan tinggal di lingkungan masyarakat penutur B1 tersebut, berusaha menguasai B1 untuk keperluan hidup dengan masyarakat sekitarnya. Dan tidak mungkin bisa hidup tanpa menguasai bahasa msyarakatnya. Selain itu, mereka memperoleh situasi kondusif karena semua orang di lingkungannya menggunakan bahasa secara aktif. Bahkan jika tidak mampu mengusai bahasa masyarakat sekitarnya, mereka tidak memiliki identitas diri sebagai anggota masyarakat. Proses ini terjadi secara alamiah dan tidak ada satu orang pun yang gagal menguasai B1-nya (Pranowo, 2014:73-74).

Sementara kita yang belajar bahasa di sekolah justru banyak melakukan kesalahan berbahasa. Bahkan ketika diuji dan dinilai ada yang tidak lulus. Hal ini terjadi bukan saja untuk mempelajari B2 atau bahasa asing, tetapi juga ketika mereka mempelajari B1. Banyak anak Indonesia yang diberi pelajaran B1 sebagai mata pelajaran muatan lokal, ternyata banyak yang tidak mahir. Untuk itu, kita perlu 
memahami tentang proses penguasaan bahasa kedua atau bahasa asing dari hasil penelitian tiga ahli, yaitu Krasen (1976), Bialystok (1979), dan Stevicks (1980).

a. Proses Belajar Bahasa Model Krashen

Penelitian Krashen (1976) terhadap proses penguasaan bahasa kedua atau bahasa asing orang dewasa menyimpulkan bahwa proses penguasaan bahasa anak kecil berbeda dengan orang dewasa. Berdasarkan hasil penelitiannya, Krashen mengemukakan ada lima teori penting yang selanjutnya dijadikan dasar oleh peneliti lain. Kelima teori tersebut, di antaranya:

1. Hipotesis pemerolehan dan belajar bahasa (the acquisition-and learning hypothesis)

2. Hipotesis urutan alamiah (the natural order hypothesis)

3. Hipotesis monitor (the monitor hypothesis)

4. Hipotesis masukan (the input hypothesis)

5. Hipotesis filter efektif (the effective filter hypothesis)

Hipotesis pemerolehan dan belajar bahasa adalah hipotesis yang menyetakan bahwa anak kecil dalam proses menguasai bahasa pertama terjadi ambang sadar (sub-consiousness) dan bersifat alamiah (natural). Proses ini disebut pemerolehan (acquisition). Orang dewasa dalam proses menguasai bahasa kedua atau bahasa asing terjadi secara sadar (consciousness) melalui bentuk-bentuk bahasa dan mewujudkannya dalam bentuk verbal. Orang dewasa menguasai bahasa melalui kaidah-kaidah formal bahasa. Proses ini disebut belajar (learning) (Pranowo, 2014:5). Kesimpulannya bahwa proses pengusaan bahasa bagi orang dewasa berbeda dengan anak kecil.

b. Proses Belajar Bahasa Model Bialystok

Proses belajar bahasa model Bialystok (1978) diorganisasikan dalam tiga tataran, yaitu input, knowledge, dan output. Tataran input berupa pengalaman berbahasa pembelajar yang telah dipajan (expouser) melalui belajar membaca dan belajar berbicara. Dengan demikian, semakin banyak anak memperoleh kesempatan belajar membaca atau berbicara akan semakin banyak input yang diterima.

Tataran knowledge berupa cara penyimpanan informasi. Cara penyimpanan informasi meliputi penyimpanan secara implisit berupa pengetahuan intuitif. Hal ini 
sesuai dengan istilah pemerolehan oleh Krashen dan istilah pengetahuan figurative oleh Piaget. Cara penyimpanan informasi secara eksplisit berupa pengetahuan bahasa secara sadar. Ha ini sesuai dengan istilah belajar yang dipakai oleh Krashen dan istilah pengetahuan operatif yang dipakai oleh Piaget. Penyimpanan informasi secara eksplisit juga berupa pengetahuan lain yaitu perwujudan hubungan informasi bahasa dengan budaya dan gesture. Pengetahuan eksplisit mempunyai tiga fungsi, di antaranya:

1) Sebagian dasar informasi baru sebelum disimpan dalam pengetahuan implisit;

2) Sebagai gudang informasi yang selalu terungkap secara eksplisit; dan

3) Sebagai system artikulasi untuk pengetahuan implicit yang mungkin dipakai secara eksplisit.

Pengetahuan implicit hnaya mempunyai satu fungsi yaitu untuk menyimpan semua informasi tentang bahasa target yang diperlukan untuk mengungkapkan dan memahami bahasa.

Tataran output bahasa adalah gambaran pemahaman dan pengungkapan bahasa. Pengungkapan bahasa dibedakan dalam dua tipe yaitu pengungkapan spontan atau pengungkapan segera, dan pengungkapan lamban.

c. Proses Belajar Bahasa Model Stevicks

Stevicks (1980) mengikuti jejak Krashen dan Bialystok untuk mengetahui teori Monitor. Istilah Stevicks untuk menggambarkan proses penguasaan bahasa digambarkan dalam bentuk diagram yang disebut diagram Levertove Machine (mesin tenaga). Diagram penguasaan bahasa yang digambarkan oleh Stevicks menjelaskan ciri-ciri sebagai berikut:

1) Hasil belajar disimpan dalam gudang pemerolehan;

2) Belajar bahasa bisa menjadi bahan output;

3) Peranan dan fungsi pemerolehan dan belajar tidak terlalu pisah secara ketat;

4) Faktor afeksi menjadi rheostat (ptensiometer) yang bisa membuat pembelajar sensitif terhadap sistem yang diperoleh. Dalam situasi tertentu seseorang mungkin dapat berbicara sangat lancer, tetapi pada waktu lain mungkin sangat lamban. Hal ini terjadi jika proses monitor sedang berlangsung. 
Jika digambarkan dalam bentuk bagan, "Levertove-Machine" sebagai berikut:

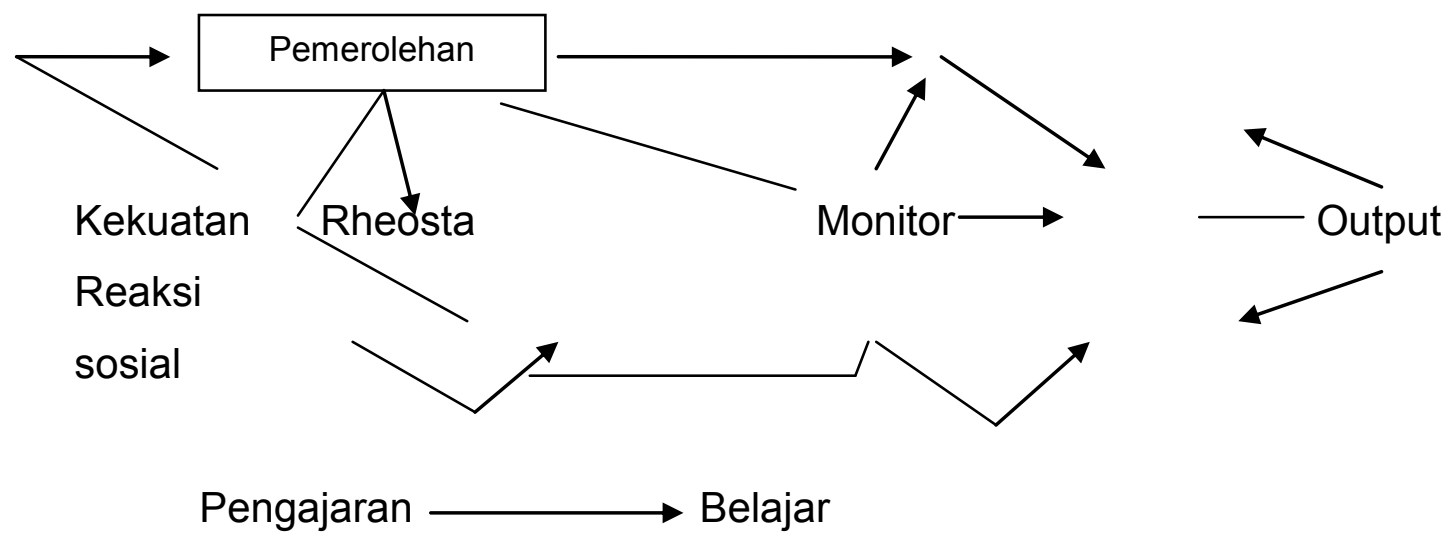

Bagan 1. Levertove-Machine

(Pranowo, 2014:83)

\section{Bahasa dan Citra Pikiran}

Kita dapat melacak hubungan antara bahasa dan berpikir dengan mudah, cobalah dengan mencoba memikirkan sesuatu tanpa menggunakan bahasa. Tentu tidak bisa kita melakukannya. Kita bisa melihat jelas seseorang yang pikirannya kacau mengakibatkan bahasanya kacau juga. Kadang juga jika seseorang sedang memikirkan sesuatu yang berat, yang bersangkutan tidak berselera untuk bicara. Ada juga yang berpendapat bahwa bahasa merupakan cermin pikiran, apa yang dibicarakan adalah apa yang dipikirkan. Bahasa terbentuk dari pikiran, atau bentuk bahasa (secara individual dan spontan) meniru atau mengikuti bentuk pikiran atau ide. Akan tetapi jika kita mau lebih jeli melihat, sesungguhnya bahasa itu hanyalah "wujud" dari ide atau pikiran saja. Sehingga analisa bahasa dengan melepaskannya dari analisa ide adalah kesesatan. Artinya, tidak mungkin ada bahasa tanpa ada ide, begitu pula sebaliknya.

Jadi berhati-hatilah (tetapi bukan takut) dalam berbahasa. Seseorang dapat menilai bobot intelektualitas kita dari apa yang kita ucapkan dan tuliskan. Citra kecerdasan kita terwujud dalam bahasa yang kita gunakan. Dardjowidjojo (2009) mendaftar beberapa korpus bahasa yang mencerminkan pola pikir bangsa kita. Yang pertama disebut dengan gejala kontradiksi, seperti kasus sumbangan wajib dan 
cukup jelas sekali. Ada kontradiksi pengertian sumbangan dan wajib, juga pengertian cukup dan jelas sekali.

Gejala anomali juga menghinggapi pola pikir kita yang berpola "Kejarlah Daku Kau Kutangkap". Judul film ini memang sengaja diciptakan secara sadar, namun ada yang tidak disadari bahwa ungkapan yang kita lontarkan bersifat anomali. Ungkapan tersebut antara lain: mengejar ketinggalan, mengentaskan kemiskinan, dan mencerdaskan kehidupan bangsa. Bandingkan kata mengejar ketinggalan dengan mengejar maling, dan mengejar bis. Konsep mengejar itu perbuatan yang akan mendapatkan apa yang kita kejar. Mengejar ketinggalan hasil yang kita dapat adalah ketinggalan. Kata kerja mengentaskan menyatakan bahwa kita memperoleh apapun yang kita entas. Dengan mengentas pakaian yang dijemur maka kita akan memperoleh pakaian. Pantas saja jika kita tertinggal terus dan miskin terus. Ungkapan mencerdaskan kehidupan bangsa juga kurang tepat karena yang dicerdaskan itu bersifat (+nsan, +bernyawa). Bukankah kita seharusnya mencerdaskan manusia Indonesia?

\section{Bahasa dan Citra Kepribadian}

Kepribadian seseorang ditentukan oleh etika yang diyakininya. Etika berbahasa ini sangat erat berkaitan dengan pemilihan kode bahasa, norma-norma sosial, dan sistem budaya yang berlaku dalam satu masyarakat. Oleh karena itu etika berbahasa memiliki atauran (a) apa yang harus kita katakan pada waktu dan keadaan tertentu kepada seseorang partisipan tertentu berkenaan dengan status sosial dan budaya dalam masyarakat itu; (b) ragam bahasa apa yang paling wajar kita gunakan dalam situasi sosiolinguistik dan budaya tertentu; (c) kapan dan bagaimana kita menggunakan giliran berbicara kita, dan menyela pembicaraan orang lain; (d) kapan kita harus diam; (e) bagaimana kualitas suara dan sikap fisik kita dalam berbicara itu. Seseorang dapat dikatakan pandai berbicara apabila menguasai tata cara atau etika berbahasa itu.

Beberapa hal yang perlu diperhatikan dalam kesantunan berbahasa adalah sebagai berikut :

(1) kesantunan itu merupakan bagian dari ujaran; jadi bukan ujaran itu sendiri. 
(2) Pendapat pendengarlah yang menentukan apakah kesantunan itu ada pada ujaran.

(3) Kesantunan itu dikaitkan dengan hak dan kewajiban penyerta interaksi. Yang artinya apakah ujaran terdengar santun atau tidak ini diukur berdasarkan apakah si petutur tidak melampaui haknya kepada lawan bicara dengan apakah si penutur memenuhi kewajiban kepada lawan bicaranya.

Sopan santun makna berbicara sering kali berhubungan dengan personal yang bersifat interpersonal atau dapat kita katakan juga etika berbahasa terkait dengan retorika interpersonal yang memiliki sejumlah prinsip sopan santun, apabila penutur tidak memperhatikan salah satu prinsip-prinsip sopan santun dalam retorika interpersonal, sebagai bagian pembahasan filsafat bahasa terminologi Grice yang juga dibahas Leech (Rahardi, 2005:60-65) sebagai berikut: (1) maksim kearifan, maksim ini mengungkapkan buatlah kerugian orang lain sekecil mungkin dan buatlah keuntungan orang lain sebesar mungkin; (2) maksim kedermawanan, maksim ini menyatakan buatlah keuntungan diri sendiri sekecil mungkin dan buatlah kerugian diri sendiri sebesar mungkin; (3) maksim pujian, maksim ini menyatakan kecamlah orang lain sedikit mungkin dan pujilah orang sebanyak mungkin; (4) maksim kerendahan hati, maksim ini menyatakan pujilah diri sendiri sedikit mungkin; kecamlah diri sendiri sebanyak mungkin; (5) maksim kesepakatan, maksim ini menyatakan usahakanlah ketaksepaktan antara diri dan orang lain terjadi sedikit mungkin dan usahakan agar kesepakatan antara diri dengan orang lain terjadi sebanyak mungkin; (6) maksim simpati, .maksim ini menyatakan kurangilah rasa anti pati antara diri dengan orang lain hingga sekecil mungkin dan tingkatkanlah rasa simpati sebanyak-banyaknya antara diri dengan orang lain.

Citra buruk kepribadian kita juga ditentukan oleh akibat penggunaan unsur bahasa yang melanggar teori kesantunan. Teori kesantunan yang paling berpengaruh diletakkan oleh Brown \& Levinson (1978 dan direvisi 1987). Pusat teori kesantunan Brown \& Levinson adalah konsep 'muka' (face). Istilah 'muka' bermakna 'reputasi' atau 'nama baik'. Dalam teori kesantunan 'muka' dipahami sebagai perasaan citra diri individual; citra ini dapat hancur, dipertahankan, atau ditingkatkan melalui interaksi dengan orang lain. Muka memiliki dua aspek-'positif' dan 'negatif'. 
Muka positif individu dicerminkan oleh keinginan disukai, disetujui, dihargai oleh orang lain. Muka negatif individu dicerminkan oleh keinginan tidak diganggu atau terbebani, memiliki kebebasan bertindak terhadap suatu pilihan. Ketidaksantunan dikarenakan adanya keterancaman muka bagi si petutur yang mengakibatkan adanya keterancaman muka yang mengacu ke citra diri setiap orang yang dituju.

Kesantunan juga dapat terganggu karena penggunaan diksi sarkastik. Secara etimologis, sarkasme berasal dari perancis yang bahasa latinnya sarcasmus asal katanya sarkasmos atau sarkazo. Arti dari sarkazo itu sendiri adalah daging yang tertusuk atau hati yang tertusuk. Jadi sarkazo itu adalah sesuatu yang dihujamkan dan menyebabkan rasa sakit yang mendalam. Dalam perkembangannya kata sarkazo lebih dikenal dengan kata sarx-sarkos yang artinya menyindir dengan tajam atau sindiran yang tajam (Webster's World Encyclopedia, 2000). Sedangkan dalam penggunaan dewasa ini lebih kita kenal dengan kata sarcasm atau dalam bahasa Indonesia sarkasme.

Sarkasme adalah penggucapan yang dilakukan secara amat kasar yang diduga akan menyakiti hati orang lain. Sarkasme adalah kata-kata yang biasa digunakan untuk pengucapan kata-kata yang pahit dan kasar. Penggunaan kata-kata ini untuk mengejek, cemooh atau menyindir yang diduga akan menyakiti hati orang lain dan hal ini melanggar kesantunan dalam berbahasa. Sarkasme adalah penggunaan katakata yang diduga melanggar kaidah-kaidah kesantunan berbahasa sehingga menimbulkan efek emosi tertentu, misalnya terhina, sakit hati, tidak enak, marah, dan lain-lain.

Sarkasme yang penggunaan diksinya tidak pada tempatnya maka kata-kata tersebut akan terdengan kasar dan tidak santun, dengan demikian ketepatan dan kesesuaian dan pilihan kata ini perlu diperhatikan dalam bahasa manapun semua konsep dinyatakan dengan kata. Kita dapat berbahasa apabila menguasai sejumlah kata-kata. Ketepatan dan kesesuaian pemilihan kata ini perlu diperhatikan karena penulisan apapun, baik itu penulisan pada media masa ataupun pada penulisan ilmiah menginginkan ketepatan dan keajekan baik dalam makna dan bentuk. Begitu juga yang dilakukan oleh seorang pengarang untuk mewakili ide-ide ataupun pikiran 
ke dalam bentuk tulisan haruslah tepat, karena kata merupakan salah satu unsur dasar penting bahasa.

Dalam memilih kata ada dua persyaratan harus diperhatikan yaitu, (1) ketepatan dan (2) kesesuaian. Persyaratan ketepatan menyangkut makna, aspek logika kata-kata, kata-kata yang dipilih harus secara tepat mengungkapkan apa yang ingin diungkapkan. Dengan demikian, pendengar atau pembaca juga menafsirkan kata-kata tersebut tepat seperti maksud yang diinginkan. Dalam penggunaan diksi ini harus diperhatikan, apakah kata-kata itu bermakna konotatif, denotatif termasuk kata umum, kata khusus dan juga diksi yang baku.

Makna denotatif adalah bahasa kamus atau definisi utama suatu kata sehingga lawan dari pada konotasi-konotasinya atau makna-makna yang ada kaitannya dengan, sedangkan makna konotatif adalah segala sesuatu yang kita pikirkan apabila kita melihat kata tersebut, yang mungkin dan juga mungkin tidak sesuai dengan makna sebenarnya. Berdasarkan pengertian di atas maka ragam konotasi dapat dibagi menjadi, (a) konotasi baik yang mencakup pula konotasi tinggi dan konotasi ramah; (b) konotasi yang tidak baik mencakup konotasi berbahaya, tidak pantas, tidak enak, kasar, keras; (c) konotasi netral atau biasa, yang mencakup pula konotasi bentukkan sekolah, konotasi kanak-kanak, konotasi hipokoristik, dan konotasi bentuk nonsens (Tarigan, 1986). Dalam kaitan dengan sarkasme lebih mempersoalkan penggunaan diksi yang berkonotasi tidak baik.

Konotasi Tinggi bisa terjadi bahwa kata-kata sastra dan klasik lebih indah dan anggun terdengar oleh telinga umum; oleh karena itu kita tidak perlu heran bahwa kata-kata seperti itu mendapat konotasi tinggi atau nilai rasa tinggi. Konotasi Ramah bisa terjadi di dalam kehidupan sehari-hari yang sering menggunakan bahasa daerah dengan demikian terjadilah bahasa campuran yang kadang-kadang lebih terasa ramah dari pada bahasa Indonesia karena hal ini membuat kita merasa lebih akrab dan dapat saling merasakan satu sama lain; Konotasi Berbahaya ini erat sekali berhubungan dengan kepercayaan masyarakat yang bersifat magis. Dalam saat-saat tertentu dalam kehidupan masyarakat, kita harus berhati-hati mengucapakan suatu kata supaya jangan terjadi hal-hal yang tidak kita ingini, hal-hal yang mungkin mendatangkan marabahaya. Konotasi berbahaya juga terkait dengan efek yang 
ditimbulkan secara sosial. Konotasi Tidak Pantas dalam kehidupan sehari-hari dalam kehidupan masyarakat terdapat sejumlah kata yang jika diucapkan tidak pada tempatnya, kata-kata tersebut mendapat nilai rasa yang tidak pantas. Konotasi Tidak Enak ada sejumlah kata yang karena biasa dipakai dalam hubungan tidak atau kurang baik, maka tidak enak didengar oleh telinga dan mendapat nilai rasa yang tidak enak. Konotasi Kasar adakalanya kata-kata yang dipakai oleh rakyat jelata terdengar kasar dan mendapat nilai rasa kasar. Konotasi Keras melebih-lebihkan suatu keadaan kita biasa memakai kata-kata atau ungkapan. Dilihat dari segi arti maka hal itu dapat disebut hiperbola, dan dari segi nilai rasa atau konotasi hal serupa itu dapat disebut konotasi keras. Konotasi Bentukan Sekolah bahwa setiap nilai rasa biasa mempunyai suatu kesejajaran dengan nilai rasa yang dipelajari atau nilai rasa bentukan sekolah. Konotasi Kanak-Kanak ini biasa terdapat dalam dunia kanakkanak. Konotasi Hipokoristik terutama sekali dipakai dalam dunia kanak-kanak, yaitu sebutan nama kanak-kanak yang dipendekkan lalu diulang. Konotasi Bentuk Nonsens sudah sangat lazim dipakai, sama sekali tidak mengandung arti.

Dengan demikian, dapat disimpulkan bahwa apabila maksud dan tujuan lain ingin dicapai dan dimengerti oleh pendengar atau pembaca maka hendaknya katakata yang digunakan kata-kata yang sudah dikenal oleh pendengar atau pembaca. Misalnya kata-kata yang populer akan lebih cepat dikenal dan lebih efektif dari pada kata-kata yang muluk-muluk atau kata-kata yang belum dikenal.

\section{Efek Bahasa yang Santun (Baik) terhadap Kepribadian dan Kesehatan}

Mengapa kita wajib berkata yang baik dan santun? Ini merupakan salah satu ajaran inti ajaran agama Islam (juga agama lainnya). Penjelasan yang logis dan praktis adalah hasil penelitian Dr. Masaru Emoto. Dr. Masaru Emoto melakukan penelitian selama 2 bulan bersama sahabatnya Kazuya Ishibashi (seorang ahli sains yang mahir menggunakan mikroskop). Masaru yang menyelesaikan pendidikannya di Yokohama Municipal University berhasil mendapatkan foto kristal air dengan membekukan air pada suhu -25 derajat Celsius dan menggunakan alat foto berkecepatan tinggi. Lalu ditelitilah air dengan menggunakan respon kata-kata, gambar, serta suara. Hasilnya luar biasa, sebagaimana yang sudah dibaca banyak 
orang. Air, katanya, bisa menerima pesan. Bahkan dalam bukunya yang lain, "The Hidden Message in Water", Masaru mengatakan, air seperti pita magnetik atau compact disk.

Air mengenali kata tidak hanya sebagai sebuah desain sederhana, tetapi air dapat memahami makna kata tersebut. Saat air sadar bahwa kata yang diperlihatkan membawa informasi yang baik maka air akan membentuk kristal. Jika kata positif yang diberikan (dipajankan secara tulisan atau dibunyikan), maka kristal yang terbentuk akan merekah luar biasa laksana bunga yang sedang mekar penuh. Sebaliknya, jika kata-kata negatif yang diberikan, maka akan menghasilkan pecahan kristal dengan ukuran yang tidak seimbang. Bahkan berbentuk buruk tidak membentuk kristal apapun. Mungkin juga air dapat merasakan perasaan orang yang menulis kata tersebut.

Berdasarkan penelitian Dr. Masaru, semakin jelas terlihat bahwa kualitas air dapat menjadi lebih baik atau lebih buruk, bergantung pada informasi yang diterimanya atau bahasa yang dipajankan kepadanya. Hal ini membuat kita yakin bahwa kita, manusia, juga dipengaruhi oleh informasi yang kita terima karena $70 \%$ tubuh manusia dewasa adalah air.

Konsekuensi logisnya adalah manusia, sebagai makhluk yang sebagian besarnya terbentuk dari air, sudah seharusnya diberikan atau dipajankan informasi/ucapan/pikiran yang baik. Jika kita melakukan hal ini, pikiran dan tubuh kita akan menjadi sehat. Di pihak lain, jika kita menerima informasi yang buruk, kita akan merasakan sakit.

\section{Penutup}

\section{Kesimpulan}

Beberapa kesimpulan dari pembahasan ini, di antaranya:

a. Bahasa sebagai alat komunikasi bermakna bahwa bahasa merupakan deretan bunyi yang bersistem, berbentuk lambang, bersifat arbitrer, bermakna, konfensional, unik, universal, produktif, bervariasi, dinamis, manusiawi, dan alat interaksi sosial yang menggantikan individual dalam menyatakan sesuatu kepada lawan tutur dalam suatu kelompok sosial sebagai alat untuk berkomunikasi dan identitas penuturnya. 
b. Bahasa sebagai citra pikiran bermakna bahwa bahasa terbentuk dari pikiran, atau bentuk bahasa (secara individual dan spontan) meniru atau mengikuti bentuk pikiran atau ide. .

c. Bahasa sebagai citra kepribadian bermakna bahwa bahasa berkaitan dengan etika berbahasa yang diyakininya. Etika berbahasa ini sangat erat berkaitan dengan pemilihan kode bahasa, norma-norma sosial, dan sistem budaya yang berlaku dalam satu masyarakat. Dengan menggunakan bahasa dengan memperhatikan etika berbahasa maka pribadi seseorang akan dikatakan baik.

\section{Saran}

a. Bagi pembaca sebaiknya lebih banyak lagi membaca literatur yang ada khususnya literatur dari penulis yang ahli dalam bahasa, sehingga diharapkan mampu memahami konsep secara mendalam tentang hakikat bahasa yang seutuhnya.

b. Bagi penulis lanjutan sebaiknya mencari literatur-literatur yang terbaru baik dalam bentuk text book, e-book, atau jenis lainnya tentang kajian hakikat bahasa sehingga diharapkan mampu memahami dan menuangkan konsep bahasa secara mendalam dan mengajarkannya sebagai sebuah ilmu.

c. Bagi mahasiswa sebaiknya kita berdiskusi setelah membaca pembahasan ini sehingga diharapkan menemukan pemahaman yang komprehensif tentang hakikat bahasa.

\section{DAFTAR PUSTAKA}

Alisjahbana, St. Takdir. (1978). Tata Bahasa Baru Bahasa Indonesia I. Jakarta: Dian Rakyat.

Bloch, Bernard \& Trager. (1984). Outline of Linguistic Analysis, dalam Henry Guntur Tarigan, Psikolinguistik. Bandung: Angkasa.

Bloomfield, L. (1933). Language. New York: Holt, Tenehardt and Wingston.

Brown, P \& S.C. Levinson. (1987). Politeness: Some Universals of Language Use. Cambridge: CUP.

Chaer, A. (2012). Linguistik Umum. Jakarta: Rineka Cipta. 
Dardjowidjojo, S. (1982). Dasar-Dasar Neurofisiologis dalam Penguasaan Bahasa, Seminar Pengajaran Bahasa. Jakarta.

Dardjowidjojo, S. (2009). "Bahasa dan Pola Pikir Bangsa Kita" Kongres Internasional Masyarakat Linguistik Indonesia 5-7 November 2009, di Batu, Malang.

Devitt, M. \& Hanley, R. (2006). The Blackwell Guide to the Philosophy of Language. USA: Blackwell Publishing Ltd.

Emoto, M. (1999). Message from Water. Tokyo: HADO Kyoikusha.

Emoto, M. (2007). Mukjizat Air, The Miracle of Water. Jakarta: Gramedia Pustaka Utama.

Hill, A. A. (1958). Introduction to Linguistic Structure. New Tork: Harcourt.

Kusmiarti, R., Yuniati, I., \& Noermanzah. (2020). Improving Student Communication Skills In Learning Indonesian Language Through Collaborative Learning. Retrieved from osf.io/9km3u. International Journal of Scientific and Technology Research, 9(1).

Noermanzah, Emzir, \& Lustyantie, N. (2018). President Joko Widodo's Rhetorical Technique of Arguing in the Presidential Speeches of the Reform Era. International Journal of Applied Linguistics and English Literature, 7(5), 119. doi:10.7575/aiac.ijalel.v.7n.5p.117

Noermanzah, N. (2017). Struktur Kalimat Tunggal Bahasa Sindang di Kota Lubuklinggau dan Pengaruhnya dalam Pembelajaran Bahasa Indonesia. AKSIS: Jurnal Pendidikan Bahasa dan Sastra Indonesia, 1(1), 2. doi:10.21009/aksis.010101

Noermanzah, N., Abid, S., \& Aprika, E. (2018). Pengaruh Teknik Send a Problem terhadap Kemampuan Menulis Daftar Pustaka Siswa Kelas Xi SMA Negeri 4 Lubuklinggau. Jurnal Kajian Bahasa, Sastra Dan Pengajaran (KIBASP), 1(2), 172. doi:10.31539/kibasp.v1i2.273

Noermanzah, N., Emzir, E., \& Lustyantie, N. (2017). Variety of Rhetorics in Political Speech President of the Republic of Indonesia Susilo Bambang Yudhoyono and Joko Widodo in Educational Field. Humanus, 16(2), 221. doi:10.24036/humanus.v16i2.8103

Pateda, M. (2011). Lingustik Sebuah Pengantar. Bandung: Angkasa.

Pranowo. (2014). Teori Belajar Bahasa: untuk Guru Bahasa dan Mahasiswa Jurusan Bahasa. Yogyakarta: Pustaka Pelajar. 
Rahardi, Kunjana. 2005. Pragmatik: Kesantunan Imperatif Bahasa Indonesia. Jakarta: Erlangga.

Sausure, F. de. (1974). Course in General Linguistics. Terjemahan dari bahasa Prancis ke bahasa Inggris oleh Wade Baskin. Fontana/Coling.

Wardhough, R. (1972). Intoduction to Linguistics. New York: McGraw-Hill, Inc,. H.3 (dalam Asep Hidayat). 